\section{Organotin Compounds Suppress Testosterone Production in Leydig Cells from Neonatal Pig Testes}

\author{
Yonako Nakajima, Go Sato, Shuji Ohno, \\ and Shizuo Nakajin*
}

Department of Biochemistry, Hoshi University School of Pharmacy and Pharmaceutical Sciences, 2-4-41 Ebara, Shinagawaku, Tokyo 142-8501, Japan

(Received June 26, 2003; Accepted July 25, 2003;

Publishd online July 25, 2003)

The in vitro effects of exposure to tributyltin chloride (TBT), dibutyltin dichloride (DBT), and triphenyltin chloride (TPT) on testosterone production in isolated Leydig cells from neonatal pig testes were examined. These organotin compounds strongly suppressed human chorionic gonadotropin (10 IU/ml) or 8-bromocAMP $(0.1 \mathrm{mM})$ induced testosterone production when the cells were exposed to nontoxic concentrations. The suppression of testosterone production was dose-dependent over the concentration range of $0.03-0.3 \mu \mathrm{M}$ for TBT and DBT, and 0.01-0.3 $\mu \mathrm{M}$ for TPT. These effective concentrations for the suppression of testosterone production were lower than that of the cytotoxic concentrations of the organotin compounds in Leydig cells and were equivalent to the accumulated concentration levels that were previously reported in marine organisms.

Key words — organotin compounds, steroidogenesis, testosterone, neonatal pig, testis

\section{INTRODUCTION}

It has been pointed out in recent years there is a strong likelihood that chemicals present in the environment, termed endocrine disruptors, may adversely affect the reproduction of wild animals and cause the feminization of male organisms. It is also feared these chemicals may have deleterious effects on human health. ${ }^{1)}$ Most of the endocrine-disrupt-

\footnotetext{
*To whom correspondence should be addressed: Department of Biochemistry, Hoshi University School of Pharmacy and Pharmaceutical Sciences, 2-4-41 Ebara, Shinagawa-ku, Tokyo 1428501, Japan. Tel.: +81-3-5498-5775; Fax: +81-3-5498-5776; Email: nakajin@hoshi.ac.jp
}

ing chemicals have low estrogenic activity. They are regarded as "environmental estrogens" since they exhibit physiological activity similar to that of natural estrogen. Various studies have been conducted in relation to the binding of these chemicals with estrogen receptors, as well as to the events occurring after binding. If the production of endogenous hormones is disturbed due to exposure to endocrinedisrupting chemicals, it is highly likely disruption of the normal endocrine system may occur. It is of significant concern that serious effects will appear in development, differentiation, and reproduction if steroidogenesis is inhibited, especially when the exposure to these chemicals take place between viviparous and neonatal periods.

Organotin compounds have been widely used as a pyrolysis stabilizer in the production of polyvinyl chloride, and as a stabilizer for improving resistance to ultraviolet radiation, and as a component of shipbottom paints and fishing-net anti-fouling agents. Due to significant concerns over their toxic effects on marine organisms, their use has been regulated in the United Kingdom and the United States since 1988, and in Japan since 1990. Since then, the amount utilized is considered to have decreased. However, there are some reports that high concentrations of organotin compounds have accumulated in marine organisms due to such possible causes as biological accumulation. ${ }^{2-9)}$ The genital condition, imposex, was reported in female gastropods inhabiting coastal areas. This is a well-known effect of organotin compounds on marine organisms here and throughout, and is considered to be caused by problems related to steroidogenesis. ${ }^{10-13)}$

In this paper, with the aim of analyzing the effects of organotins on steroidogenesis in the testis, we investigated the effects of tributyltin chloride (TBT), dibutyltin dichloride (DBT), and triphenyltin chloride (TPT) on testosterone production in Leydig cells from neonatal pig testes. To use Leydig cells from neonatal pig testis in this investigation is useful for studying the effects of organotins on steroidogenesis, as will be described in the discussion. We report here for the first time that these organotin compounds strongly suppress testosterone production in Leydig cells at concentration levels that accumulate in marine organisms. 


\section{MATERIALS AND METHODS}

Materials and Chemicals _ Fresh testes from neonatal pigs (strain, LWD; 2 weeks of age) were obtained from a breeder (Chibakita Farm, Co. Ltd., Chiba, Japan) by castration and were immediately transported to the laboratory in ice-cold RPMI 1640 medium containing antibiotics $(50 \mathrm{IU} / \mathrm{ml}$ penicillin and $50 \mu \mathrm{g} / \mathrm{ml}$ streptomycin). TBT, DBT, and TPT were purchased from Sigma-Aldrich Japan KK (Tokyo, Japan). Percoll ${ }^{\circledR}$ was purchased from Amersham Biosciences Corp. (Piscataway, NJ, U.S.A.). DMEM/F-12 (1: 1 mixture of Dulbecco's modified Eagle's and Ham's F-12), RPMI 1640, and penicillin-streptomycin were purchased from Invitrogen (Carisbad, CA, U.S.A.). Collagenasedispase was obtained from Roche Diagnostics (Basel, Switzerland). Soybean trypsin inhibitor, transferrin, vitamin E, insulin, and 8-bromo-cAMP (8-Br-cAMP) were purchased from Sigma Chemical Co. (St. Louis, MO, U.S.A.). Human chorionic gonadotropin (hCG) was purchased from Wako Pure Chemical Industries, Ltd. (Tokyo, Japan). All other reagents were of the highest grade commercially available.

Preparation of Leydig Cells and Primary Culture Leydig cells were prepared from the neonatal pig testes using a modification of an enzymatic method described by Brun et al. ${ }^{14)}$ Minced testes were suspended in $0.06 \%$ collagenase-dispase containing $0.006 \%$ soybean trypsin inhibitor, and incubated at $34^{\circ} \mathrm{C}$ for $90 \mathrm{~min}$ with occasional stirring. The dispersed cells were filtered successively through 160- and 59- $\mu \mathrm{m}$ monofilament nylon meshes. The Leydig cells were then purified using a method which involves a discontinuous Percoll $^{\circledR}$ gradient. The gradient consisted of four phases; 5 , 30,58 , and $70 \%$ Percoll $^{\circledR}$, respectively. The filtered cell suspension was centrifuged at $2500 \times g$ at $4^{\circ} \mathrm{C}$ for $20 \mathrm{~min}$. The specific gravity of the Leydig cells was between 1.070 and $1.075^{15)}$ and thus the cells migrated to form a band situated between the 30 and $58 \%$ Percoll $^{\circledast}$ phases. This band was removed and washed twice with RPMI 1640 . The purity of Leydig cells was assessed by $3 \beta$-hydroxysteroid dehydrogenase (HSD) staining ${ }^{16)}$ and was found to be $91.3 \%$. The viability of the cells was evaluated by means of the trypan blue exclusion test and found to be $84.6 \%$. Isolated Leydig cells were cultured in DMEM/F-12 medium without phenol red, supplemented with $5 \mu \mathrm{g} / \mathrm{ml}$ transferrin, $10 \mu \mathrm{g} / \mathrm{ml}$ vitamin E, $5 \mu \mathrm{g} / \mathrm{ml}$ insulin, $0.1 \%$ fetal calf serum, and antibiotics in an atmosphere of $95 \%$ air $-5 \% \mathrm{CO}_{2}$ at $34^{\circ} \mathrm{C}$. Stimulation of Testosterone Production and Analysis — Pig Leydig cells $\left(6 \times 10^{4}\right.$ cells/well/ $200 \mu \mathrm{l})$ were seeded into 96 -well culture plates and precultured for $24 \mathrm{hr}$. The medium was then exchanged and an organotin compound dissolved in ethanol was added. The final concentrations of the alcohol solvents in the assay mixture did not exceed $1.0 \%(\mathrm{v} / \mathrm{v})$ and were confirmed not to obstruct testosterone production. After $3 \mathrm{hr}$, the cells were stimulated with hCG $(10 \mathrm{IU} / \mathrm{ml})$ or $8-\mathrm{Br}$-cAMP $(0.1 \mathrm{mM})$ for $24 \mathrm{hr}$. After incubation, the testosterone content of each well was determined by EIA (Testosterone EIA kit; Cayman Chemical Company, Ann Arbor, MI, U.S.A.) or RIA (DPC total testosterone kit; Diagnostic Product Corporation, Los Angeles, CA, U.S.A.).

Cytotoxicity Test — The cytotoxicity of each chemical was tested using the CytoTox $96^{\circledR}$ nonradioactive cytotoxicity assay kit (Promega Corp., Madison, WI, U.S.A.) for determining lactate dehydrogenase (LDH) activity.

Statistical Analysis — Statistical analysis of data was performed with the Student's $t$-test. The point of minimal statistical significance was set at $p<0.05$.

\section{RESULTS AND DISCUSSION}

The effects of exposure to TBT, DBT and TPT on testosterone production in isolated Leydig cells from neonatal pig testes were examined. Figs. 1A$1 \mathrm{C}$ shows the effects of these organotin compounds on testosterone production induced by the addition of hCG $(10 \mathrm{IU} / \mathrm{ml})$. A significant decrease in testosterone production was observed at $0.03-0.3 \mu \mathrm{M}$ TBT and DBT and at $0.01-0.3 \mu \mathrm{M}$ TPT. Further, by reason that the testosterone production in Leydig cells is dependent on cAMP, the effects of exposure to these organotin compounds on 8-Br-cAMP induced testosterone production was also examined. As shown in Figs. 1D-1F, testosterone production was significantly decreased at $0.03-0.3 \mu \mathrm{M}$ TBT, $0.1-0.3 \mu \mathrm{M}$ DBT, and $0.01-0.3 \mu \mathrm{M}$ TPT.

At the same time, the cytotoxic effects of TBT, DBT, and TPT on Leydig cells were examined by determining LDH activity in the conditioned medium. As shown in Fig. 2, a significant increase in LDH activity was confirmed at $1-10 \mu \mathrm{M}$ TBT and $0.3-10 \mu \mathrm{M}$ DBT and TPT, and the increases were $8.7-15.6 \%, 7.9-18.2 \%$, and $8.4-12.2 \%$ of total LDH 

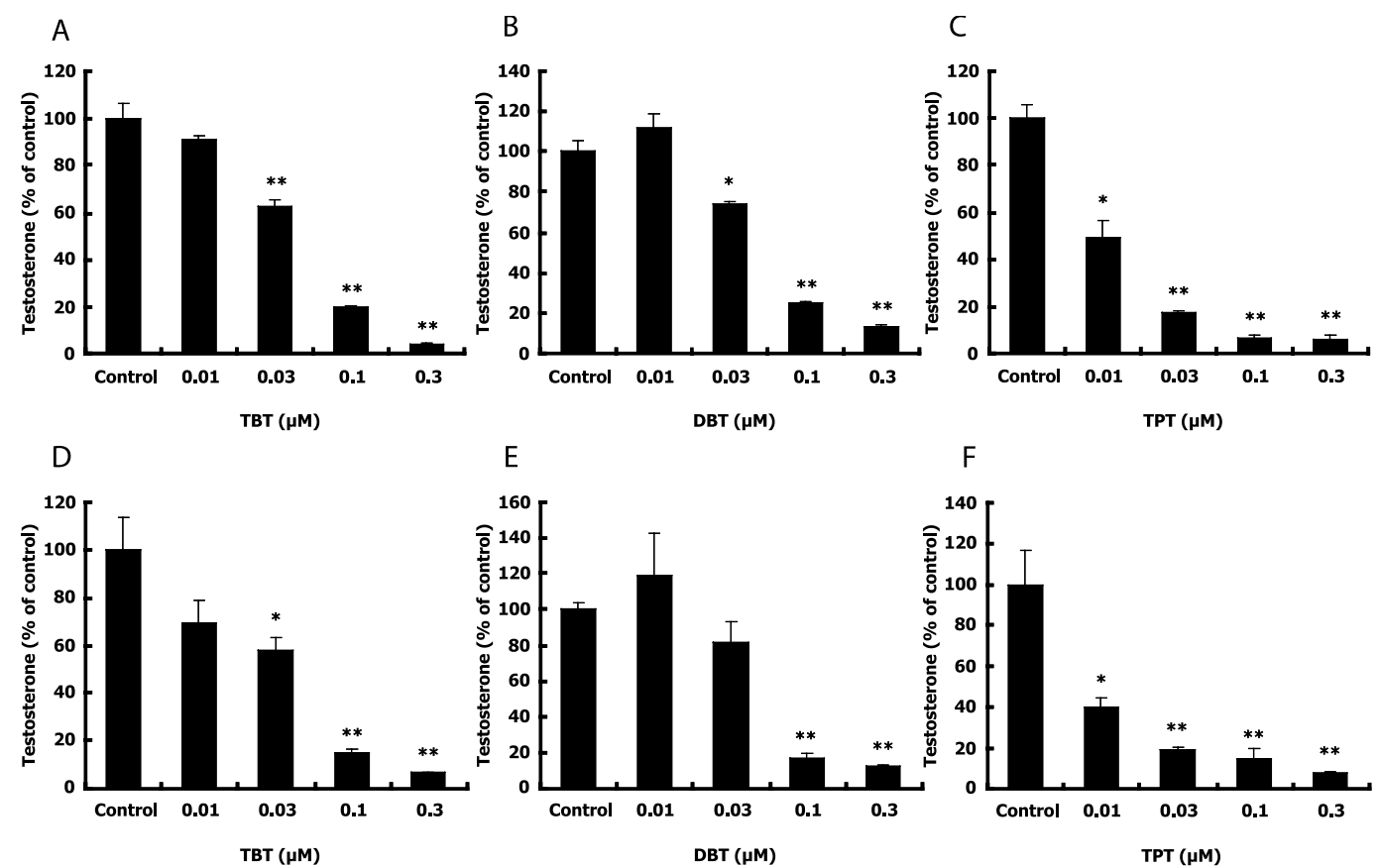

Fig. 1. Effect of Exposure to TBT (A, D), DBT (B, E) and TPT (C, F) on Testosterone Production by Leydig Cells from Neonatal Pig Testes

Each organotin compound was added to the medium at the various concentrations, after $3 \mathrm{hr}$, cells were stimulated with hCG (10 IU/ml; A, B, C) or 8-Br-cAMP (0.1 mM; D, E, F) for $24 \mathrm{hr}$. Control value (vehicle) is $1.21 \pm 0.04$ (A), $1.70 \pm 0.09$ (B), $1.18 \pm 0.03$ (C), $2.05 \pm 0.27$ (D), $1.06 \pm 0.02$ (E) and $1.19 \pm 0.20 \mathrm{mg} / \mathrm{ml}(\mathrm{F})$, respectively. Each column represents the mean with S.E.M. $(n=3)$. Asterisks denote significant difference from the control value (treatment of vehicle). ${ }^{*} p<0.05$ and ${ }^{* *} p<0.01$.
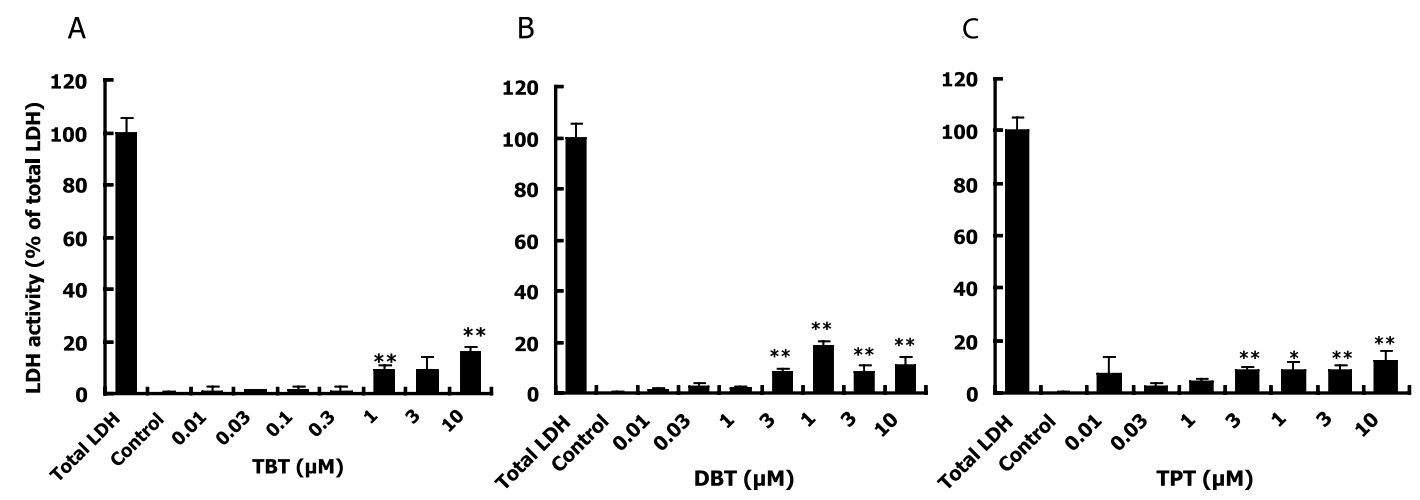

Fig. 2. Cytotoxicity Test of TBT (A), DBT (B) and TPT (C) in Leydig Cells from Neonatal Pig Testes

The cytotoxicity of each chemical was tested using the CytoTox $96^{\circledR}$ cytotoxicity assay kit for determining LDH activity. The cells were exposed to various concentrations of organotin compounds for $24 \mathrm{hr}$, and then $\mathrm{LDH}$ activity of conditioned medium was determined. Total LDH means the maximum LDH release from cells by complete lysis. Each column represents the mean with S.E.M. $(n=3)$. Asterisks denote significant difference from the control value from untreated cells. ${ }^{*} p<0.05$ and ${ }^{* *} p<0.01$.

activity, respectively. These cytotoxic concentrations of the organotin compounds were higher than that which suppresses testosterone production. Accordingly, it is clear that the suppression of testosterone production in pig Leydig due to exposure to TBT, DBT, and TPT is not due to the cytotoxicity.

Leydig cells are used as a model for the majority of investigations on the regulation testicular ste- roidogenesis and steroidogenic enzymes. ${ }^{17)}$ Testosterone production is carried out by the $\Delta^{4}$ pathway (testosterone from pregnenolone via progesterone, $17 \alpha$-hydroxyprogesterone and androstenedione) or the $\Delta^{5}$ pathway (testosterone from pregnenolone via $17 \alpha$-hydroxypregnenolone, dehydroepiandrosterone and androstenedione) of steroidogenesis in Leydig cells. It is well known that although the $\Delta^{4}$ pathway 
is predominant in rats and mice, the $\Delta^{5}$ pathway is predominant in the testes of pigs and humans. ${ }^{18,19)}$ Pig Leydig cells are a good model for studying the regulation of human testicular steroidogenesis. ${ }^{20)}$ In this experiment, we used pig testicular Leydig cells from the neonatal stage. The neonatal pig testis contains a high volume of Leydig cells that retain their specific functions in culture for relatively long periods. ${ }^{21)}$

It is well known that the organotins TBT and TPT are used as components of ship-bottom paints and as fishing-net antifouling agents. Moreover, DBT is known as a plastic stabilizer as well as a degradation product from TBT. Although these organotin compounds show concentrations as low as several parts per trillion (ppt), some reports have revealed that a high concentration of organotin compounds, in the order of ppb, is still accumulated in marine organisms due to possible causes such as biological concentration. For instance, Ebdon et al. ${ }^{2)}$ measured the TBT, DBT, and butyltin trichloride (MBT) concentrations in oysters in the United Kingdom and found that the average concentrations were $3.1,16.1$, and $16.7 \mu \mathrm{g} / \mathrm{g}$, respectively, and their biological concentration factor was approximately 10000. Tsunoda ${ }^{3)}$ measured DBT, TBT, and TPT concentrations in fish and shellfish purchased from retail markets in Niigata, Japan and reported concentrations as high as $0.674,0.669$, and $0.186 \mu \mathrm{g} / \mathrm{g}$, respectively. By measuring various kinds of butyltin compounds, Kannan et al. $^{4-6)}$ reported that dolphins captured in the Mediterranean Sea in 1992 contained $1.2-2.2 \mu \mathrm{g} / \mathrm{g}$ wet weight total butyltin compounds, sea ducks from the west coast of British Columbia, Canada showed a maximum of $1.1 \mu \mathrm{g} / \mathrm{g}$, and river otters in the American states of Washington and Oregon showed a maximum of $2.6 \mu \mathrm{g} / \mathrm{g}$. Shim et $^{\text {al. }}{ }^{7)}$ measured TBT and TPT concentrations in Pacific oysters in Chinhae Bay, Korea, and reported 0.095$0.885 \mu \mathrm{g} \mathrm{Sn} / \mathrm{g}$ and $0.155-0.678 \mu \mathrm{g} \mathrm{Sn} / \mathrm{g}$, respectively. Moreover, they also reported that TBT could be biologically concentrated in oysters up to 25000 times. Harino et al $^{8)}$ measured TBT and TPT concentrations in 11 kinds of fish in the ports of Osaka and Yodo River, Japan, and reported values ranging from $0.011-0.082 \mu \mathrm{g} / \mathrm{g}$ wet weight, and from $0.01-$ $0.030 \mu \mathrm{g} / \mathrm{g}$ wet weight, respectively. Guruge and Tanabe $^{9)}$ examined rabbit fish captured from the west coast of Sri Lanka, and reported 11-38 $\mu \mathrm{g} / \mathrm{g}$ wet weight as total butyltin. On the other hand, details of the amount of accumulation of organotin compounds in humans have not yet been clarified, but studies in Japan reported that the daily intake of TBT or TPT was $2.2-6.9 \mu \mathrm{g}$ or $0.7-5.4 \mu \mathrm{g}$, respectively. ${ }^{22-24)}$

The results of the present study show that TBT $(0.01-0.3 \mu \mathrm{M})$, DBT $(0.01-0.1 \mu \mathrm{M})$, and TPT (0.01$0.1 \mu \mathrm{M})$ at nontoxic concentrations suppress testosterone production induced by hCG or 8-Br-cAMP. A concentration of $0.1 \mu \mathrm{M}$ of these organotin compounds is equivalent to $0.033,0.030$, and $0.039 \mu \mathrm{g} /$ $\mathrm{ml}$, respectively. Testosterone is a critical factor for sexual differentiation of mammals during the viviparous and perinatal periods. Accordingly, there is concern that if testosterone production is inhibited, especially when exposure to these organotins takes place during these critical periods, it will adversely affect not only wildlife reproduction but also human health.

Currently, imposex is considered to occur because P450 aromatase (CYP19), which catalyzes estrogen production from androgen, is inhibited by organotin compounds, thereby increasing androgen levels. ${ }^{25)}$ In support of this, some reports have revealed that these organotin compounds inhibit CYP19, which is related to steroid hormone synthesis, especially estrogen synthesis, in humans. Saitoh et al. ${ }^{26)}$ reported that TBT exposure to human granulosa-like tumor cells inhibited aromatase activity due to decreased CYP19 mRNA levels at the transcriptional level. Heidrich et al. ${ }^{27)}$ reported that human placental aromatase activity is directly inhibited by TBT $\left(\mathrm{IC}_{50}=6.2 \mu \mathrm{M}\right)$ or DBT but not by MBT and tetrabutyltin. However, Nakanishi et al. ${ }^{28)}$ reported that the trialkyltin compounds TBT and TPT were potent stimulators of human placental aromatase activity through the use of human choriocarcinoma cells. It is very interesting how organotin compounds are involved in the disruption of steroidogenesis.

Our results show that organotin compounds suppress testosterone production induced by tropic stimulation. To clarify the mechanism of action of suppression, restraining the increase in cAMP, the induction of steroidogenic acute regulatory protein, as well as the induction of CYP11A, CYP17, $3 \beta$ HSD (type 2) and /or 17 $\beta$-HSD (type 3) must be examined. We intend to clarify the mechanism of action in the near future.

Acknowledgements This work was supported in part by a Grant-in-Aid from the Ministry of Education, Culture, Sports, Science and Technology of Japan and by Health Sciences Research Grants from the Ministry of Health, Labour and Welfare of Japan. 


\section{REFERENCES}

1) Colborn, T., von Seal, F. S. and Sato, A. M. (1993) Developmental effects of endocrine-disrupting chemicals in wildlife and humans. Environ. Health Perspect., 101, 379-384.

2) Ebdon, L., Evans, K. and Hill, S. (1989) The accumulation of organotins in adult and seed oysters from selected estuaries prior to the introduction of UK regulations governing the use of tributyltinbased antifouling paints. Sci. Total Environ., 83, 6384.

3) Tsunoda, M. (1993) Simultaneous determination of organotin compounds in fish and shellfish by gas chromatography with a flame photometric detector. Tohoku J. Exp. Med., 169, 167-178.

4) Kannan, K., Corsolini, S., Focardi, S., Tanabe, S. and Tatsukawa, R. (1996) Accumulation pattern of butyltin compounds in dolphin, tuna, and shark collected from Italian coastal waters. Arch. Environ. Contam. Toxicol., 31, 19-23.

5) Kannan, K., Senthilkumar, K., Elliott, J. E., Feyk, L. A. and Giesy, J. P. (1998) Occurrence of butyltin compounds in tissues of water birds and seaducks from the United States and Canada. Arch. Environ. Contam. Toxicol., 35, 64-69.

6) Kannan, K., Grove, R. A., Senthilkumar, K., Henny, C. J. and Giesy, J. P. (1999) Butyltin compounds in river otters (Lutra canadensis) from the northwestern United States. Arch. Environ. Contam. Toxicol., 36, 462-468.

7) Shim, W. J., Oh, J. R., Kahng, S. H., Shim, J. H. and Lee, S. H. (1998) Accumulation of tributyl- and triphenyltin compounds in Pacific oyster, Crassostrea gigas, from the Chinhae Bay System, Korea. Arch. Environ. Contam. Toxicol., 35, 41-47.

8) Harino, H., Fukushima, M. and Kawai, S. (2000) Accumulation of butyltin and phenyltin compounds in various fish species. Arch. Environ. Contam. Toxicol., 39, 13-19.

9) Guruge, K. S. and Tanabe, S. (2001) Contamination by persistent organochlorines and butyltin compounds in the west coast of Sri Lanka. Mar. Pollut. Bull., 42, 179-186.

10) Smith, B. S. (1981) Male characteristics on female mud snails caused by antifouling bottom paints. $J$. Appl. Toxicol., 1, 22-25.

11) Horiguchi, T., Hyeon-Seo, C., Shiraishi, H., Shibata, Y., Soma, M., Morita, M. and Shimizu, M. (1998) Field studies on imposex and organotin accumulation in the rock shell, Thais clavigera, from the Seto Inland Sea and the Sanriku region, Japan. Sci. Total Environ., 214, 65-70.

12) Morcillo, Y. and Porte, C. (1999) Evidence of endocrine disruption in the imposex-affected gastropod Bolinus brandaris. Environ. Res., 81, 349354.

13) Horiguchi, T., Shiraishi, H., Shimizu, M., Yamazaki, S. and Morita, M. (1995) Imposex in Japanese gastropods (neogastropoda and mesogastropoda): effects of tributyltin and triphenyltin from antifouling paints. Mar. Pollut. Bull., 31, 402-405.

14) Brun, H. P., Leonard, J. F., Moronvalle, V., Caillaud, J. M., Melcion, C. and Cordier, A. (1991) Pig Leydig cell culture: a useful in vitro test for evaluating the testicular toxicity of compounds. Toxicol. Appl. Pharmacol., 108, 307-320.

15) Benahmed, M., Reventos, J. and Saez, J. M. (1983) Steroidogenesis of cultured purified pig Leydig cells: Effects of lipoproteins and human chorionic gonadotropin. Endocrinology, 112, 1952-1957.

16) Levy, H., Deane, H. W. and Rubin, B. L. (1956) Visualization of steroid- $3 \beta$-ol-dehydrogenase activity in tissues of intact and hypophysectomized rats. Endocrinology, 65, 932-943.

17) Saez, J. M. (1994) Leydig cells: endocrine, paracrine, and autocrine regulation. Endocr. Rev., 15, 574-626.

18) Ruokonen, A., Laatikainen, T., Laitinen, E. A. and Vihko, R. (1972) Free and sulfate -conjugated neutral steroids in human testis tissue. Biochemistry, 11, 1411-1416.

19) Ruokonen, A. and Vihko, R. (1974) Steroid metabolism in testis tissue: concentrations of unconjugated and sulfated neutral steroids in boar testis. J. Steroid Biochem., 5, 33-38.

20) Clark, A. M., Chuzel, F., Sanchez, P. and Saez, J. M. (1996) Regulation by gonadotropins of the messenger ribonucleic acid for $\mathrm{P} 450$ side-chain cleavage, $\mathrm{P} 450_{17 \alpha}$-hydroxylase $/ \mathrm{C}_{17,20}$ - lyase, and $3 \beta$ hydroxysteroid dehydrogenase in cultured pig Leydig cells. Biol. Reprod., 55, 347-354.

21) Mather, J. P., Saez, J. M. and Haour, F. (1981) Primary cultures of Leydig cells from rat, mouse and pig: advantages of porcine cells for the study of gonadotropin regulation of Leydig cell function. Steroids, 38, 35-44.

22) Tsuda, T., Inoue, T., Kojima, M. and Aoki, S. (1995) Daily intakes of tributyltin and triphenyltin compounds from meals. J. AOAC Int., 78, 941-943.

23) Yamamoto, I. (1994) Pollution of fish and shellfish with organotin compounds and estimation of daily intake. Hokkaido Igaku Zasshi, 69, 273-281.

24) Sekizawa, J. (1998) Health and environmental risk assessment of organotin pollution in Japan. Kokuritsu Iyakuhin Shokuhin Eisei Kenkyusho Hokoku, 116, 126-131.

25) Bettin, C., Oehlmann, J. and Stroben, E. (1996) TBTinduced imposex in marine neogastropods is 
mediated by an increasing androgen level. Helgol. Meeresunter., 50, 299-317.

26) Saitoh, M., Yanase, T., Morinaga, H., Tanabe, M., Mu, Y. M., Nishi, Y., Nomura, M., Okabe, T., Goto, K., Takayanagi, R. and Nawata, H. (2001) Tributyltin or triphenyltin inhibits aromatase activity in the human granulosa-like tumor cell line KGN. Biochem. Biophys. Res. Commun., 289, 198-204.

27) Heidrich, D. D., Steckelbroeck, S. and Klingmuller,
D. (2001) Inhibition of human cytochrome P450 aromatase activity by butyltins. Steroids, 66, 763769.

28) Nakanishi, T., Kohroki, J., Suzuki, S., Ishizaki, J., Hiromori, Y., Takasuga, S., Itoh, N., Watanabe, Y., Utoguchi, N. and Tanaka, K. (2002) Trialkyltin compounds enhance human CG secretion and aromatase activity in human placental choriocarcinoma cells. J. Clin. Endocrinol. Metab., 87, 2830-2837. 